NAGY ZSÓFIA ${ }^{1}$

KÖTETLENÜL

\title{
AZ ANGELUSZ RÓBERT TÁRSADALOMTUdOMÁNYI SZAKKOLLÉGIUM TANULMÁNYKÖTETÉRŐL
}

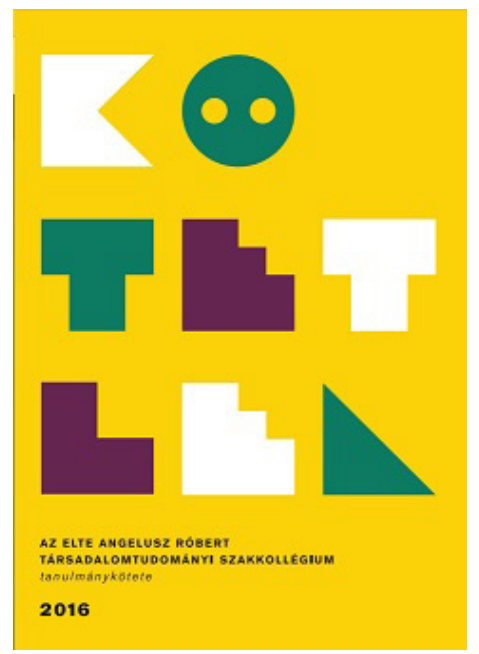

Kötetlen 2016

Az ELTE Angelusz Róbert Társadalomtudományi Szakkollégiumának tanulmánykötete

Budapest: ELTE Angelusz Róbert Társadalomtudományi Szakkollégium, 2016

DOI: $10.18030 /$ sOCIO.HU.2017.1.70

Az Angelusz Róbert Szakkollégium Kötetlen címet viselő évkönyvének szervezőelve hagyományosan és tudatosan nem tematikus: célja a kutatóközösség szerteágazó tevékenységének bemutatása, összefoglaló a szakkollégium tagjainak éves teljesítményéről. Az évkönyv idei kötetére ez a koncepció csak korlátozottan érvényes: a gyűjtemény első blokkja egy nagyobb kutatás, a Kontúr Közhasznú Egyesülettel együttműködésben megvalósított Hős utcai terepmunka eredményeinek bemutatása több tanulmányon keresztül. Ezt a blokkot követik a tematikusan egymáshoz nem kapcsolódó tudományos tanulmányok.

A kötet Hős utca-blokkja három tanulmányt: egy felvezető, módszertani fókuszú írást, illetve két kutatási beszámolót tartalmaz, melyek közül az első célja a lakásmobilitási mintázatok bemutatása, a másodiké az oktatási és iskoláztatási helyzet összefüggéseinek elemzése.

A Kovács Annamária - Szeitl Blanka - Vigvári András által jegyzett, Terepen a Hős utcában című, a kötetet és az első blokkot nyitó tanulmány hármas fókuszú: egyrészt rövid leírását adja a kutatás helyszínéül és témájául szolgáló Hős utcai telepnek, másrészt ismerteti azokat a módszertani problémákat és rájuk adott válaszokat, amik az empirikus munkát befolyásolták, végezetül a Kontúr Közhasznú Egyesülettel való együttműködést mint közösségfejlesztő projektet mutatja be.

A felvezető tanulmány értéke jóval több, mint segédegyenest rajzolni az olvasó számára a konkrét kutatások kontextualizálásához és keretezéséhez. Ahogyan azt a szerzők kiválóan felismerik, a módszertani kihívások mögött, amivel a kutatás szembenéz, mélyebb társadalmi folyamatok rejlenek. A dilemma, tudniillik a 
kutatási alanyok azonosításának, elérésének és megszólításának nehézsége, nem választható el sem azoktól a helyi sajátosságoktól, sem azoktól a makrotársadalmi folyamatoktól, amelyek kontextusában a kutatás zajlik. A felvezető tanulmány maga is azonosít mögöttes okokat, utalva többek között Angelusz Róbert (2000) megállapítására a társadalmi nagycsoportok láthatóságának csökkenéséről. Bár kétségtelenül igaz az, ahogyan a tanulmány szerzői írják, hogy a megváltozó kutatási egységek, a nehezen elérhető/körülhatárolható csoportok mint a kutatások új fókuszai a módszertanok újragondolását igénylik, ugyanakkor fontos látni, hogy a probléma súlya korántsem csak a kicsi és rejtőzködő csoportok empirikus kutatására korlátozódik - elég itt csak a 2016-os Brexit, illetve az amerikai elnökválasztás előrejelzési hibáira utalni.

Tourangeau (2014) klasszifikációját alkalmazva a nehezen felmérhető csoportok kapcsán felmerülő módszertani problémákra, nyilvánvalóvá válik, hogy a Hős utcai kutatás a problémák valamennyi formájával és szintjével találkozott. Megjelennek a mintavételi keret problémái (hard-to-sample); a nehezen azonosíthatóság kihívása (hard-to-identify); a kapcsolatfelvétel nehézsége (hard-to-contact); végül a meggyőzés és az interjúzás problémái (hard-to-convince, hard-to-interview) (Tourangeau 2014). A módszertani dilemmákra egy lehetséges, innovatív és eredményes választ jelent a közösségi együttmúködés az empirikus munka során. A felvezető tanulmány záró szakasza a Kontúr Közhasznú Egyesülettel való együttmúködésről részben a módszertani kihívásokra adott válaszként is olvasható.

Kovács Barbara Nóra Utak a szegregátumba című tanulmánya a Hős utcai telep lakásmobilitási mintázatait mutatja be, a kutatás kvalitatív eredményeire, a lakók életútjainak bemutatására építve. Az elemzés következtetése, hogy a Hős utca sajátos ürt tölt be a budapesti lakáspiacon, ahol egyrészt Budapest vidékhez viszonyított relatív előnye, másrészt a Hős utca Budapesten belül az alacsony jövedelműeket vonzó jellege a meghatározó tényezők.

A tanulmány a konkrét kutatáson keresztül rávilágít a magyar városszociológia sajátos helyzetére és perspektivájára: míg a szegregátumok, a „white flight”, a prekárius lakhatás nem Kelet-Európa specifikumai, mindezeknek a problémáknak a posztszocialista verziója ugyanakkor több és más, mint egy globális probléma helyi kiadása. Mind a budapesti lakáspiac közelmúltbeli történetének alakulása, mind a kutatásban megjelenő élet- és családtörténetek magukban hordozzák ezt a sajátos, kettős helyzetet, ahol gyakran a kapitalizmus által hajtott változások egyben az államszocializmus összeomlásának romjain valósulnak meg. A tudomány a nyugati nagyvárosok arculatának átalakulását a schumpeteri „kreatív rombolás” fogalmában ragadja meg. Ebből nem csak az következik, ahogyan Neil Brenner (2009) megfogalmazza, hogy a városkutatásnak, és azon belül a kritikai városkutatásnak is újra és újra meg kell fogalmaznia önmagát, hanem az is, hogy a posztszocialista országokban zajló városkutatásnak a kreativitás és rombolás aránytalanságaira, megbomló egyensúlyára is fókuszálnia kell. Az interjúkon közös szálként átivelő megküzdési stratégia, a lakók - ki-, be- és visszaköltözők - improvizációja, amivel a különböző fordulópontokra reagálnak, ennek a változékony és kiszolgáltatott helyzetnek érzékletes bemutatására alkalmasak.

A szegregált oktatás és a kirekesztettség dimenzióinak kapcsolata a Hős utcai telepen, Alacsony Zsóka és Földesi Judit tanulmánya a fent bemutatott szegregátum és oktatás kapcsolatát vizsgálja a telepen élő gyermekek és szüleik iskolához való kapcsolódásának bemutatásán keresztül. A kutatás árnyaltan elemzi, hogy elvárások, funkciók és szolgáltatások terén az iskolával való kapcsolat korántsem írható le egyértelmúen negatívan, 
ahogyan lehetséges a telepen élők között is eltérő stratégiákat azonosítani. Ugyanakkor mindezen moderáló tényezők mellett igaz az, hogy a kirekesztettség formái jellemzik és sújtják a közösséget, összességében pedig megvalósul a szegregált oktatás.

"A gazdagok irányítják a teret; a szegényeket foglyul ejti” - írja David Harvey (1973) ma már klasszikus Social Justice and the City címú múvében. Így válik a periféria egyszerre földrajzi, és társadalmi tartalommal is bíró kifejezéssé. A tanulmány a kirekesztettség fogalmát és konkrét aspektusait hívja segítségül ennek a periférikus helyzetnek a leírására. Az iskolai kutatás érdekes részlete a jelentésadás problémája: mit jelent a tér annak szereplői számára. Bár a vizsgált iskola neve - Borostány Utcai Általános Iskola - nem utalna a szegregátumra, a megkérdezett pedagógus is csak Hős utcai iskola néven emlegeti azt.

A Hős utcai kutatást bemutató tanulmányok érzékenyen mutatnak arra rá, hogy vizsgálódásuk alanyai nem nyomorba dermedt, mozdulatlan szereplők, hanem dinamikusan mozgó, a bizonytalanságokra és kockázatokra reagáló emberek. Hogyan ragadható meg ez az idő- és térbeli dinamizmus analitikusan? A prekárius lakhatás fogalma - ami jóval több, mint a szükséges védőhálók megléte vagy hiánya - alkalmas lehet az empirikus eredmények ilyen szellemú vizsgálatára. A fogalom célja reflektálni az érintett társadalmi csoportok mozgására a különböző lakhelyek között, amelyeket a gyakori költözés, kényszerűség jellemez, gyakran olyan lakóhelyek irányába, amelyek maguk is bizonytalanok, rossz minőségűek. A prekárius lakhatás fogalma a kiszolgáltatottság mellett Hulse és Saugeres (2008) megfogalmazása szerint magában foglalja a privát szféra hiányát (mind a lakáson belül, mind pedig a lakások között), a biztonságérzet, kényelemérzet hiányát, illetve a cselekvőképesség elvesztésének élményét. A prekárius lakhatás tehát nem egyszerűen kirekesztettség, hanem összetett, gyakran kumulatív kockázatoknak való kitettség. Ezek a kockázatok gyakran a Hős utcai tanulmányokban bemutatott mintázatot veszik fel: a bajok csőstül jönnek, az azoknak való kiszolgáltatottság pedig elhúzódó.

A Hős utcai kutatást bemutató tanulmányokat követően Brecsok Anna Ágnes Önkormányzati oktatás vs. állami köznevelés című tanulmánya közigazgatás-tudományi szempontból vizsgálja az elmúlt évek tanigazgatásának főszereplője, a KLIK múködését. A kutatás módszertana támaszkodik egyrészt a jogszabályok és rendeletek elemző vizsgálatára, másrészt kulcsinterjúkra és adatfelvételre, amelyek a helyi oktatás szereplőit célozták meg.

A bemutatott változások annak a nagyobb átalakulásnak képezik részét, amelynek során az elmúlt években a humán közszolgáltatások számos területén (egészségügy, közüzemi szektor) (Horváth-Péteri 2012) erősödött meg az állami befolyás. Bár jellemző ennek a centralizációnak a szúken vett politikai értelmezése, a közoktatás rendszerváltás óta eltelt története és ennek nemzetközi kontextusba helyezése arra is rámutat, hogy a jelenség - azaz a helyi és állami szintek közti feladatmegosztás dinamikus alakulása - korántsem egyedülállóan magyar jelenség; továbbá nagyobb politikai „divatokat” is követ: a nemzetállam kialakulásának korszelleméhez a centralizáció, a 20. század második feléhez a decentralizáció politikája illeszkedik (Forray-Kozma 2013). Ezek azok a tágabb folyamatok és trendek, a politikai-ideológiai törésvonalakkal együtt, amelyek következményeként a decentralizáció-recentralizáció kérdése gyakran erősen értéktelített problémaként jelenik meg még a szakpolitikai viták berkein belül is; ahol a decentralizáció szükségképpen a szakmai autonómiával és függetlenséggel, a recentralizáció pedig ennek a függetlenségnek a megcsorbításával jelent egyet. Az összefüggés azonban ennél sokkal bonyolultabb, ahogyan azt az európai példák sokszínűsége is mutatja (Sáska 2013). Brecsok Anna Ágnes 
tanulmánya a fent leírt ideológiai előfeltevésektől mentesen igyekszik arra keresni a választ, milyen következményekkel járt a centralizáció. Miközben egy korábbi egyensúlyi rendszer megbomlása bontakozik ki szemünk előtt, ami elsősorban az irányítás-szervezés területén jelenik meg, egyelőre nem látszanak azok a potenciális előnyök, amelyeket a centralizáció ígért: a finanszírozás javulása, az iskolák közti különbségek csökkentése, illetve a stratégiai tervezés. A kutatást záró szerzői álláspont, amely szakmailag a decentralizáció felé való ellépés mellett teszi le a voksot, a tanulmány meggyőző lezárása. Emellett arra is rámutat, hogy az átalakulások sorában, ahogyan azt Forray és Kozma (2013) leírják, az újraállamosítás korántsem a végállomást jelenti, a kérdés, tudniillik, hogy kié az iskola, újrafogalmazandó válaszokat kíván .

Bacsák Dániel tanulmánya, Az antiszociális személyiségzavar, avagy a fából lett vaskarika esete a pszichiátriában a pszichiátriai diagnosztikának arra a stigmatizáló gyakorlatára fókuszál, ahol az antiszociális személyiségzavar diagnózisa mint egyszerre medikalizáló és kriminalizáló praxis múködik. A medikalizáció kultúrájának fogalmára építve Bacsák precízen mutatja be, miért tautologikus gyakran maga a pszichiátriai diagnózis, és hogyan kettőzi meg a gyakorlat a bűncselekmény elkövetőjének meg- és elítélését.

A kritikai kriminológia perspektivájából a bűncselekmény nem az egyén személyes tulajdonsága, hanem társadalmi, többek között konstrukciós és címkézési folyamatok végkimenetele. Bacsák tanulmánya így kiváló példa - a szociológiai képzelőerő fogalmát kölcsönvéve (Mills 1959) - a kriminológiai képzelőerő (Barton 2007) gyakorlatba való átültetésére. Mills klasszikus konceptualizációját a kriminológiára alkalmazva egyértelmú a különbségtétel személyes gondok (personal trouble) és közösségi ügyek (public issue) között. Míg a személyes gond individuális, privát probléma, a közösségi ügy társadalmi eredetű és társadalmi válaszra tart igényt. A kriminológiai képzelőerő célja ennek szellemében nem más, mint annak a domináns, individualizált bűncselekményekről és büntetésekről való gondolkodásmódnak a kikezdése, amely a tanulmány bemutatása szerint is meghatározza a magyar igazságszolgáltatást.

A Foucault által jelentősen inspirált kritikai kriminológia ugyanakkor megteremti saját kritikáját, többek között a Parr (2013) és mások által képviselt, magát kritikai realistaként azonosító iskola formájában. A kritikai realisták felvetése szerint a kritikai kriminológia megmaradva a diskurzusok elemzésének szintjén nem képes továbblépni az adott diskurzus dekonstrukcióján, deskripcióján, ennél azonban többre van szükség: a mögöttes struktúrák, érdekek, kézzelfogható valóságok feltárására. Nem kell igazságot tennünk ebben a kritikai-kritikai realista vitában ahhoz, hogy mégis további kérdések feltevésére inspiráljon minket. Mi a pszichiátria mint diszciplína sajátos tudáshatalmi érdeke és pozíciója, amelyben a biopolitika sajátos szereplőjévé válik? Bacsák fontos megjegyzése, hogy a medikalizáció kultúrája nem azt jelenti, hogy a pszichiátria kolonizálná az életünket - a pszichiátria tehát nem mint represszív, hanem mint produktív erő jelenik meg ebben a konstellációban. Az elemzési horizont kitágítását jelenthetné az egyes szereplők érdekeinek, struktúrában való elhelyezkedésüknek a vizsgálata, különös tekintettel a magyar történeti kontextusra.

Szarka Zsanett Kovásznai György: Habfürdő című elemzése a rendező azonos címú animációs filmjéről, illetve annak elő- és utótörténetéről különleges színt képvisel a kötetben, amennyiben a film elemzésén keresztül törekszik állítások megfogalmazására a Kádár-korhoz való viszony témájában. Szarka célja a film bemutatásán keresztül annak alátámasztása, hogy az a maga sajátos módján rendszerkritikus és tabudöntögető volt. 
Az elemzést az teszi társadalomtudományosan relevánssá, hogy szerzője felismeri a tárgy kettős helyzetét: a film egyszerre múvészeti teljesítmény, az utókor társadalomtudósa számára azonban emléktárgy is. Ez utóbbi minőségében a jelen kutatója forrásként használhatja az államszocialista valóság megértéséhez, ahogyan Szarka is teszi: „Kovásznai mindazt át tudja adni a Habfürdőben, amit nem olvashatunk ki a történelemkönyvekböl" (130). Nem megfeledkezve azonban arról, hogy a jelen nézője és a múlt filmje közti interakció szükségképpen fordítói folyamat, ráadásul az animációs film mint emlékezeti hely, fiktiv, a szerző a film világát kiegészíti a film korabeli recepciójának bemutatásával. A hangsúly a film kortárs meg nem értő fogadtatásán van, amivel szemben az utókor, illetve maga a tanulmányíró értékelése áll. Az írásban ebből a kontrasztból származó válaszok további, fontos kérdések feltevésére is alkalmasak, amik közül itt csak egyet említek. A társadalomtudományos kutató számára az egyik lehetséges analitikus út annak a kérdésnek a felvetése, hogy az államszocializmus társadalmi emlékezetéhez milyen hozzájárulással szolgál egy korabeli fikciós film, ha a hangsúlyt a müfajra - ez esetben az animációra- helyezzük? Moritz (1997) tanulmányát segítségül hívva felvethető, hogy az államszocialista kultúrában relatív szabadságot élvező animációs filmrendezők múvei egyszerre funkcionálhattak - és válhattak értelmezhetővé - két ellentétes módon: egyrészről, mint a társadalomkritika terepei (a nagyobb szabadságfok, a szubverzív forma, a gyakran értetlen cenzorok miatt); másrészről éppen ellenkezőleg: mint a kritika felszámolásának és lehetetlenségének eszközei (a formátum nehezen olvashatósága és túlrajzoltsága miatt). Moritz (1997) következtetése, tudniillik, hogy ez a kettősség létrehoz egy olyan „interaktív rendszert”, amelyben az animációs film „csavaros” mondanivalóját a közönségnek kell a maga számára kibontania, bár sok hasonlóságot mutat a "sorok között olvasás” gyakorlatának leírásával, egy további releváns állításhoz is vezet: ez az értelmezési ambivalencia, állítja Moritz, az, ami az államszocialista időszak animációs filmjeit megmenti az aktuálpolitikai mondanivalónak való alárendelődéstől, és teszi azokat időtállóvá.

Lehotai Orsolya Jobboldali „feminizmus" című tanulmánya a kritikai diskurzuselemzés eszközét alkalmazva a magyarországi nőpolitikai közbeszédre igyekszik azonosítani azokat a konzervatív perspektívákat, amiket gyakran antifeminista jelzővel látnak el a nyilvánosságban. Lehotai ezzel a címkével szemben meggyőzően mutatja be, hogy a különböző konzervatív diskurzusok sajátos emancipatív stratégiákat képesek felmutatni, ennyiben tehát többek, mint a feminista mozgalom egyszerú ellenmozgalmai.

Lehotai tanulmányának fókusza legalább hármas, és valamennyi aspektus önállóan is fontos kutatási területet fed le. Első lépésben arra vállalkozik, hogy elhelyezze a feminista diskurzust a magyarországi rendszerváltás utáni közbeszédben. A dilemma, amiben a feminizmus találja magát, miközben specifikusan magyar jegyekkel rendelkezik, számos ponton kísértetiesen hasonlít a Judith Stacey által több mint három évtizede megfogalmazottakra: „A feminizmust ma önértékelési válság sújtja. Egyrészt, az új jobboldal felemelkedése egy olyan antifeminista társadalmi mozgalom megjelenése, elkötelezett női aktivisták légióival, amely arra a fájdalmas beismerésre kényszeríti a feministákat, hogy nem vagyunk képesek beszélni mindazok nevében vagy mindazokhoz, akiket képviselni reméltünk." (Stacey 1983: 559). Ennek magyarországi megfelelőjét fogalmazza meg Pető Andrea is egy interjúban: „(...) miközben feministák és baloldali liberálisok alig tudnak valakit a nőkérdéssel megszólítani, addig a hagyományos női szerepekhez ragaszkodó politikai oldal képes a nöket tömegesen mobilizálni." (Gács 2003). Miközben tehát fontos vita, hogy alkalmazható-e, és ha igen, hogyan a feminista leírás a konzervatív nőpolitikákra, társadalmi jelentőségük elvitathatatlan - ez adja a kutatás relevanciáját. 
Második lépésben az írás arra vállalkozik, hogy azonosítsa a feminizmuson belüli konzervatív irányzatokat, meghatározza sajátos pozíciójukat a mainstream feminizmushoz képest. A konzervatív diskurzusok közti közös pont megtalálásának kísérlete - ahol a tanulmány többek között a rendszerkritika hiányát, a nemi dichotómia megerősítését és az antikommunista diskurzusba való beágyazottságát emeli ki - további fontos kérdéseket vet fel. Az azonosulási pontok definiálását ugyanis tovább bonyolítja, hogy mind a feminizmus, mind a konzervativizmus maga is transzformációkon ment át az elmúlt évtizedekben. Míg a nyolcvanas években tudományos konszenzus övezte azt a megállapítást, hogy a konzervatív feminizmusok közös jellemzője például a heteronormativitás, illetve a patriarchális társadalom elleni küzdelem elsődlegességének tagadása (Stacey 1983), kérdés, hogy ezek közül a tételek közül mi igaz ma a konzervatív feminista diskurzusokra mind nemzetközi környezetben, mind a magyar viszonylatban; továbbá, hogy mi okozza az adott idő- és térbeli eltéréseket.

Harmadszor, a tanulmány további célja az egyes konzervatív feminizmusok egymáshoz való viszonya, a köztük lévő különbségek bemutatása. Míg Pető Andrea (2003) korábbi munkájában három konzervatív feminista diskurzust különít el (hagyományos; emancipált, spirituális), Lehotainál a paletta jóval sokszínúbb: a családalapú, a reformista feminista, a „keresztényfeminista”, a keresztény fundamentalista nőpolitikai, a radikális jobboldali, az antifeminista diskurzusokat megkülönböztetve. Ez a harmadik aspektus veti fel a legtöbb tudományosan izgalmas kérdést: milyen törésvonalakat, akár rivalizálásokat fed el a valóban megtévesztő, de jelenlévő antifeminizmus mint a belső kohéziót megteremteni kívánó gyűjtőfogalom; milyen új különbségek jelennek meg a konzervatív diskurzusokon belül. Így például a radikális jobboldali és a családalapú diskurzus versengése különös fénytörésben jelenik meg, ahol a feleket köti az emberi jogi nyelvezettől való tartózkodás normatív elvárása. A reformista feminista diskurzus önálló, konzervatív diskurzusként való azonosítása Barát Erzsébet szóhasználatát (2005) alkalmazva a legkevésbé evidens, leginkább különálló indoklást igénylő döntés Lehotai részéről, ezt érdemes lenne empirikus alátámasztással kiegészíteni.

Bezsenyi Tamás tanulmánya, A nem(telen)-helyek kriminológiája Augé (2012) nem-helyek koncepcióján keresztül vizsgálja a nagyvárosi búnelkövetés és deviáns magatartások térbeli aspektusait. Míg Augé megfogalmazásában a nem-hely negáció: nem rendelkezik identitáskonstruáló erővel, a bűnszervezetek gyakorlatai jelentéstulajdonító, azaz transzformatív erővel bírnak: így válnak Augé nem-helyei Bezsenyi megfogalmazásában nemtelen helyekké, ahol a negációt a normarendszerhez való sajátos viszony váltja fel.

A nem-hely fogalmával kapcsolatban számos analitikus nehézség merül fel: maga Augé a koncepció megfogalmazása óta fokozatosan jut el arra az álláspontra, hogy hasznosabb azt metaforaként, és kevésbé tetten érhető jelenségként megragadnunk. A kérdést, amelyhez értékes hozzájárulás a tanulmány, tovább bonyolítja az erőszak és tér, a specifikusan nem-helyek sokrétú kapcsolata: elég csak az erőszak sajátos megjelenési formájára, a terrorizmusra gondolnunk (legyen szó akár szeptember 11-ről, a londoni metrómerényletekről, a madridi robbantásokról), hogy belássuk, a kettő közötti affinitás egyszerre jelenik meg logisztikai, szimbolikus éskulturális dimenzióban. A terror hatása egyben a nem-helyek temporális aspektusára is rámutat - ahogyan Augé fogalmával szemben gyakori kritika, hogy ami ma nem-hely, holnapra tartalommal töltődhet fel - ettől nem függetlenül: a nem-hely, ahogyan ezt Augé (2012) ambivalens leírása is elismeri: jelentéstulajdonítási folyamatok eredménye. Ebből adódóan: ami adott szereplőnek, társadalmi csoportnak helyként konstituálódik, könnyen lehet nem-hely mások perspektívájából. 
A magyar társadalomtudományos gondolkodásról szóló diskurzusokból ma sem hiányoznak a különböző lemaradás-, periféria- és válságnarrativák. Az Angelusz Róbert Szakkollégium 2016-os évkönyve üdítő ellenpontként szolgál, amennyiben megmutatja, hogy a következő kutatógeneráció témaválasztásában kurrens és releváns problémákra fókuszál, megközelítésében pedig intellektuálisan és tudományosan magas színvonalat képvisel.

\section{HIVATKOZÁSOK}

Angelusz, R. (2000) A láthatóság görbe tükrei. Budapest: Új Mandátum.

Augé, M. (2012) Nem-helyek. Bevezetés a szürmodernitás antropológiájába. Budapest: Műcsarnok Nonprofit Kft.

Barát, E. (2005) The 'Terrorist Feminist': Strategies of Gate-Keeping in the Hungarian Printed Media. In Lazar, M. M. (szerk.) Feminist Critical Discourse Analysis: Gender, Power and Ideology in Discourse. London: Palgrave, 205-228.

Barton, A. - Corteen, K. - Scott, D. - Whyte, D. (2007) Introduction: Developing a Criminological Imagination. In Barton et al. (szerk.) Expanding the Criminological Imagination: Critical Readings in Criminology. Portland: Willan, 19-14.

Brenner, N. (2009) What is Critical Urban Theory? City 13(2), 198-207. http://dx.doi.org/10.1080/13604810902996466

Forray, R. K. - Kozma, T. (2013) Menekülés az iskolától. Educatio, 23(1), 23-35. Elérhető: epa.oszk.hu/01500/01551/00063/pdf/ EPA01551_educatio_2013_01_023_034.pdf [Letöltve: 2016-11-01].

Gács, A. (2003) „Elképesztő emberi teljesítmények” - Lakner Judittal, Pető Andreával és Sebök Marcellel a nőtörténetírásról beszélget Gács Anna. Elérhető: http://beszelo.c3.hu/cikkek/\%E2\%80\%9Eelkepeszto-emberi-teljesitmenyek\%E2\%80\%9D [Letöltve: 201611-01].

Harvey, D. (1973) Social Justice and the City. Baltimore: The John Hopkins Press.

Horváth, M. T. - Péteri, G. (2012) Nem folyik az többé vissza. Az állam szerepének átalakulása a víziközmú-szolgáltatásban. In Valentiny, P. - Kiss, F. L. - Nagy, Cs. I. (szerk.) Verseny és Szabályozás. Budapest: MTA KRTK, 177-200.

Hulse, K.- Saugeres, L. (2008) Housing Insecurity and Precarious Living: an Australian Exploration. AHURI Final Report No. 124. Melbourne: Australian Housing and Urban Research Institute Limited, Melbourne. Elérhető: https://www.ahuri.edu.au/research/ final-reports/124 [Letöltve: 2016-11-01].

Mills, C. W. (1959) The Sociological Imagination. Oxford: Oxford University Press.

Moritz, W. (1997) Narrative Strategies for Resistance and Protest in Eastern European Animation. In Pilling, J. (szerk.) A Reader in Animation Studies. London: John Libbey, 38-47.

Parr, S. (2013) Integrating Critical Realist and Feminist Methodologies: Ethical and Analytical Dilemmas. International Journal of Social Research Methodology, 18 (2), 193-207. http://dx.doi.org/10.1080/13645579.2013.868572

Pető, A. (2003) Napasszonyok és Holdkisasszonyok. A mai magyar konzervativ politizálás alaktana. Budapest: Balassi Kiadó.

Sáska, G. (2013) Centralizáció, decentralizáció, demokrácia. Educatio, 23(1), 3-22. Elérhető: epa.oszk.hu/01500/01551/00063/pdf/ EPA01551_educatio_2013_01_003_022.pdf [Letöltve: 2016-11-01]

Stacey, J. (1983) The New Conservative Feminism. Feminist Studies, 9(3), 559-583. http://dx.doi.org/ 10.2307/3177616

Tourangeau, R. (2014) Defining Hard to Survey Polulations. In Tourangeau, R. et al. (szerk.) Hard-to-Survey Populations. Cambridge: Cambridge University Press. Cambridge, 3-21. 